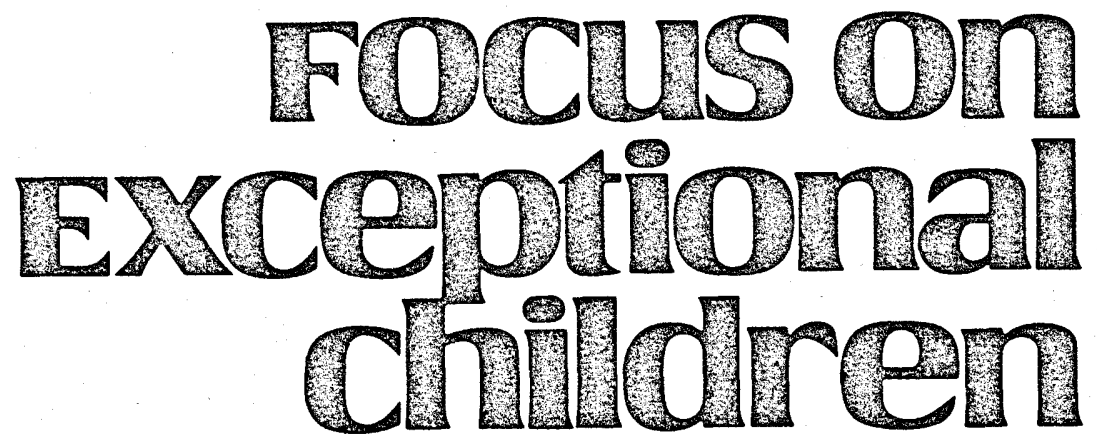

\title{
Improving the Learning of Mathematics in our Schools
}

\author{
Lelon R. Capps and Linda Simon Cox
}

In the view of many Americans, our schools have failed to produce literate graduates. Although some people always have held this view, the launching of Sputnik in 1957 gave it national and international exposure. From that time forward the "failings" of our schools repeatedly have been the subject of media attention. These failings include failing to teach respect; graduating students who cannot read, write, or spell adequately; producing students who are not literate in geography, history, the sciences, or mathematics; and the list continues.

This discussion concentrates on the area of mathematics. Internationally our students are ranked near the bottom in comparative studies of mathematics achievement. The business community finds this appalling and demands a workforce that is better educated, possesses greater skill in mathematics, is more familiar with the technology necessary to conduct business and to communicate in today's world, and, above all, has "common sense" in making decisions. There is increasing concern that America is relinquishing its role as a leader in technological advancement. As a consequence, the schools are experiencing increasing pressure to solve these problems.

The discussion here examines one aspect of a potential solution to the problem of poor mathematics achievement. We focus on specific research findings in the area of forgetting, and examine the implications for year-round schooling. The implications, of course, go far beyond the mathematics curriculum.

Lelon Capps is Professor, Curriculum \& Instruction, University of Kansas, and author, Houghton Mifflin mathematics programs $K-8$. Linda Simon Cox is formerly affiliated with the department of special education, Seattle Public Schools and Pacific Lutheran University. 
We contend that over the past three decades numerous and continual changes have taken place in the mathematics curriculum. Yet, none of these changes has silenced the critics or solved the problems. Could these continual changes in the mathematics curriculum have ignored other psychological and organizational factors that negate or neutralize the intended positive influences of the curriculum change? Over the past 30 years we have observed the move from the traditional mathematics curriculum to "new math," to "back-to-basics," to problem solving, and currently to changes emphasized in the Curriculum and Evaluation Standards for School Mathematics (National Council for Teachers of Mathematics, 1989). In April of 1991, the Professional Standards for Teaching Mathematics (National Council for Teachers of Mathematics, 1991) was released. The latest movement is characterized by the term constructivism.

Yet, this change in emphasis over the past 30 years has produced only limited success in raising student achievement and in satisfying the critics. Carpenter et al. (1984) reported the results of the National Assessment of Educational Progress from 1973, 1978, and 1982. Table 1 shows the change over the three assessments for 9-, 13-, and 17-

\section{Focus on
Exceptional
children}

ISSN 0015-511X FOCUS ON EXCEPTIONAL CHILDREN (USPS 203-360) is published monthly except June, July, and August as a service to teachers, special educators, curriculum specialists, administrators, and those concerned with the special education of exceptional children. This publication is annotated and indexed by the ERIC Clearinghouse on Handicapped and Gifted Children for publication in the monthly Current Index to Journals in Education (CIJE) and the quarterly index, Exceptional Children Education Resources (ECER). It is also available in microfilm from Xerox University Microfilms, Ann Arbor, MI. Subscription rates: Individual, \$27 per year; institutions, $\$ 36$ per year. Copyright (C) 1991, Love Publishing Company. All rights reserved. Reproduction in whole or part without written permission is prohibited. Printed in the United States of America. Second class postage is paid at Denver, Colorado. POSTMASTER: Send address changes to:

$$
\begin{gathered}
\text { Love Publishing Company } \\
\text { Executive and Editorial Office } \\
1777 \text { South Bellaire Street } \\
\text { Denver, Colorado } 80222 \\
\text { Telephone (303) } 757-2579
\end{gathered}
$$

Edward L. Meyen

University of Kansas
Glenn A. Vergason Georgia State University

Richard J. Whelan

University of Kansas Medical Center

Stanley F. Love Publisher
Carolyn Acheson

Senior Editor year-olds. The reader can readily discern the pattern over time and conclude that the curriculum changes over the specific time period did not produce an overall positive change in mathematics accomplishments of our 9-, 13-, and

\begin{tabular}{|c|c|c|c|c|c|}
\hline \multirow[b]{2}{*}{ Age } & \multirow{2}{*}{$\begin{array}{c}\text { Number } \\
\text { of } \\
\text { Items }\end{array}$} & \multicolumn{3}{|c|}{$\begin{array}{c}\text { Mean Percentage } \\
\text { Correct }\end{array}$} & \multirow{2}{*}{$\begin{array}{c}\text { Percentage } \\
\text { Change } \\
1973-82\end{array}$} \\
\hline & & 1973 & 1978 & 1982 & \\
\hline & 23 & 39.8 & 39.1 & 38.9 & -.9 \\
\hline 13 & 43 & 53.7 & 52.2 & 56.4 & $2.7^{\star}$ \\
\hline 17 & 61 & 55.0 & 52.1 & 51.8 & $-3.2^{\star}$ \\
\hline
\end{tabular}
17-year-olds.

\section{TABLE 1}

Mean Performance Levels on Three Mathematics Assessments

*Change is significant at the .05 level.

In Table 2 the assessment results are examined by content areas. Here there are some significant changes for 9and 13-year-olds, but 17-year-olds show no significant change. Note that the topics that have been more recent additions to the curriculum and have received increasing focus in more current curriculum materials predominate this list. Numeration has remained at a plateau.

TABLE 2

Change within Content Areas from 1978 to 1982

Mean Change in Percentage Correct

\begin{tabular}{lccc} 
Content Area & Age 9 & Age 13 & Age 17 \\
\hline Number and numeration & .07 & 4.0 & .0 \\
Variables and relations & -1.3 & $3.2^{\star}$ & -.5 \\
Geometry & $2.0^{\star}$ & $4.7^{\star}$ & .0 \\
Measurement & .8 & $2.6^{\star}$ & -1.3 \\
Probability and statistics & .2 & $3.7^{\star}$ & 1.2 \\
Graphics and tables & $3.0^{\star}$ & $3.2^{\star}$ & .4 \\
\hline
\end{tabular}

*Change is significant at the .05 level.

One can only conclude that the many changes in curriculum have achieved mixed results. More recent topics added to the curriculum show some positive change. The more traditional topics show no change. With regard to technological literacy, we have no reliable information. The overall picture is not encouraging.

In its publication Everybody Counts, the National Research Council (1989) describes the challenges we face. These include:

- large numbers of students leaving school without the mathematical power necessary for productive lives

- a shortage of qualified mathematics teachers

- an increasing number of minority students 
- a lack of skill acquisition in mathematics to sustain our technologically based society

- failure to compete internationally in mathematical accomplishments

- a public attitude that accepts poor school performance in mathematics

- curricula that fail to reflect the increased demand for focus on higher order thinking skills, applications of mathematics to everyday uses, and the way students learn mathematics

- failure to include the calculator and computer in instructional practices for mathematics

- excessive reliance on standardized test scores to evaluate success

- failure to stimulate the mathematical interest of today's students.

To date, our answer to the challenges has been to:

- increase the number of required courses, with little agreement as to their content

- put greater force on standardized measurements with little concern for whether those instruments reflect the content taught or skills needed in the workplace

- increase use of test scores for teacher and school accountability.

What, then, is the answer to the dilemma? Obviously there is no single answer. It does seem obvious from the two preceding paragraphs, however, that curricular change alone is not an answer but, rather, a partial solution that needs support from other aspects of the schooling process. Three sources for consideration are discussed here:

1. The role language and symbolism play in learning mathematics.

2. The role of forgetting as it relates specifically to mathematics learning and the learning disabled.

3. The effect of our school calendar as a contributing factor to low achievement in mathematics.

\section{THE LANGUAGE FACTOR IN LEARNING}

Regardless of students' abilities, the teacher of mathematics must recognize that content is not taught without language. As a society, the myth exists that if you are a skilled reader, success certainly will follow in other subjects. How is it, then, that millions of excellent readers find themselves lost in mathematics classes, especially when asked to cope with the ever present word problem? Common sense tells us that in every lesson we teach, regardless of content, we first must have students succeed in understanding the language and symbolism of the specific con- tent area. Hirsch's (1987) best seller on cultural literacy addresses this problem in an interesting manner, and it is suggested to all readers who wish to pursue the social implications of diverse populations that lack a broad base of common knowledge about our country's diversity.

Several barriers must be surmounted in the mathematics lesson for the learner to achieve successful outcomes. First, much of the language and symbolism of mathematics, or any other content area, is unique to that subject matter and would never be acquired through a reading curriculum. Words such as denominator, addend, division, polygon, function, and factor do not lend themselves to inclusion among the stories in a reading text.

As a natural consequence of the preceding barrier, a second one becomes obvious. We must recognize that the only place to learn the language and symbolism of mathematics is during the 40- to 50-minute mathematics lesson. A mathematics lesson must introduce words and symbols in much the same manner as new words would be introduced in a reading lesson. That sequence involves four basic steps. Listed in order, they are:

\section{Listen. \\ 2. Speak. \\ 3. Read. \\ 4. Write.}

These steps, of course, can overlap, but basically we hear and speak a language before we learn to read and write it.

Unlike the language in reading programs with its constant reinforcement outside the instructional period and the school, the mathematics lesson must provide the reinforcement primarily within the lesson and the classroom. As a minimum, teachers must write the words and symbols on the chalkboard for students to hear and speak and read. Written assignments then must require more than computation. The assignment must call for written reinforcement of the language and symbolism as well.

To see implications for the teacher of students with learning disabilities, we need only be reminded of factors such as the following (Meyers \& Burton, 1989):

- visual processing deficits

- auditory processing deficits

- kinesthetic deficits, and

- reasoning disorders.

In the mathematics lesson these deficits and disorders are magnified many times because of the uniqueness and abstractness of the mathematics language and symbolism. A special reason for the magnification relates to frequency of exposure to the language. Research from the field of 
reading suggests that a student should hear, speak, read, and write the terms or symbols approximately six times in an introductory lesson. Even this will not ensure acquisition into the student's usable vocabulary. What is required further is approximately 30 subsequent exposures, in context over several months time. We suggest here that this single factor-overlooked by many teachers in regular and specialized classes-is a major, contributing factor to low achievement in mathematics.

To summarize this, we again note that although reading program vocabulary is reinforced constantly at home and in social interactions, this is not the case for mathematics vocabulary and symbolism. The lack of reinforcement outside the school must be compensated for during the mathematics instructional period and the students' school day.

\section{FORGETTING AND RECOUPMENT}

Cone's (1984) literature tends to support the conclusion that language factors unique in mathematics are much more subject to forgetting. And they are more influential on achievement than are language factors unique to the subject of reading.

Over the years, a limited amount of research has been conducted on the degree of skill maintenance or skill loss for nonhandicapped students in the basic academic areas of reading, language, and arithmetic. Morrison (1924) and Irmina (1928) reported general maintenance of reading skills over the summer, and Elder (1927) and Keys and Lawson (1937) actually reported some gain over the same noninstructional interval.

Bruene (1928) reported maintenance of language skills over the summer for nonhandicapped students. More recent work by Keys and Lawson (1937) and Beggs and Hieronymus (1968), however, reported significant losses in language skills following summer break.

The research on nonhandicapped students' mathematics skill retention over the summer suggests a consistently significant loss. Bruene (1928), Schrepel and Laslett (1936), Keys and Lawson (1937), and Beggs and Hieronymus (1968) all reported significant losses in arithmetic calculation or reasoning, or both, upon student re-entry in the fall.

Thus, although the literature suggests that nonhandicapped students display significant skills loss in arithmetic after summer break, this is less conclusive in language skills. The available empirical data regarding reading skills suggest no loss and possibly some gain.

The nature of "summer forgetting" is even less clear than its occurrence or nonoccurrence. In an attempt to assess the relationship between intelligence and summer forgetting, Kohlberg (1934) found no significant correlation. Yet, Bruene (1928), Breuckner and Distad (1924), and Cook
(1942) all reported a significant positive correlation between measured intelligence and retention. Tiedeman (1948) suggested that such losses occur more readily for specific subject content; and Schrepel and Laslett's (1936) findings suggested losses in concept formation and generalization skills. Parsley and Powell (1962) and Soar and Soar (1969) contended that skill retention over summer break is a function of individual student characteristics interacting with certain classroom conditions.

Although current research is sparse, two conclusions seem warranted from the preceding review. First, the evidence tends to favor a conclusion of significant forgetting in mathematics learning over summer vacation. Second, current researchers have a major opportunity to add to the information base regarding forgetting and recoupment among regular students.

Looking at literature for handicapped students' forgetting and recoupment, (Cone, 1984) presented a less clear picture. Special educators have advocated summer, or extended-year programs for students with severe handicaps, to reduce or eliminate the problem of summer forgetting. Fredericks et al. (1978) found a positive relationship between amount of instructional time and achievement gains for students with severe handicaps. In a review of the literature on the efficacy of extended-year programs, Magliocca and Barker (1981) reported that the literature is replete with reports of summer programming for handicapped children, almost all indicating significant growth in one or another of the skill areas for different categories of handicapped conditions. Behrens (1967) reported acceleration in language skill acquisition for children with hearing impairments.

Bateman (1968) reported significant gains in cognitive and language processes for retarded children in a 6-week summer camp. Taylor and Pollock (1968) showed similar gains for trainable retarded pupils when compared to similar programs for otherwise handicapped children.

Many authors have reported significant or substantial gains during summer programs, for a full range of handicapping conditions and for all age ranges (Abordo, 1977; Baken, 1976; Brown \& Andrews, 1968; Chorost, 1975; Ellis, 1975; Fox, Wright, \& Goldstein, 1967; Hourcase, 1977; Joiner, Lodato, \& Stillman, 1972; Minton, 1976; Polansky, 1979; Riegel \& Taylor, 1973; Spivack \& Koskey, 1972; Starkovich, 1972).

Yet, Magliocca and Barker (1981) concluded that most reports do not include, as baseline, pupil performance levels at the end of the previous 180-day school year. Although evidence of gain is available, the literature is conspicuously lacking in conclusive data. Control studies with matched populations of handicapped children receiving and not receiving extended school-year programming are absent in the research literature. 
More recent studies support Magliocca and Barker's concerns. Ross (1982) compared the maintenance or nonmaintenance of skills for multiple handicapped students who did and did not attend a 6 -week summer program. The findings revealed nonsignificant difference between treatment groups on pre- and post-measures, prompting the conclusion that both populations did not "regress" or "acquire" new skills or behaviors; rather they maintained their spring student progress record scores.

McMahon (1983) evaluated the progress of 26 students recommended for an extended school year. This select subgroup of students with handicaps (whom a multidisciplinary team judged the more severe to need an extended school year) displayed a roughly $70 \%$ maintenance of skill during measured intervals, regardless of instruction or noninstruction on skills. Though nonmaintenance of skills increased slightly during noninstructional periods, only a small proportion of these students displayed such "regression" of skills.

Turner (1981) studied more than 4,000 mildly, moderately, and severely handicapped students for nearly 3 years. He reported a low probability of substantial regression/ recoupment problems for students with severe handicaps over the summer break.

Tilley, Cox, and Stayrook (1986) explored forgetting and recoupment in specific handicapped, severely handicapped, communication disordered, and hearing impaired students. The thoughtful design and thorough statistical treatment led to the following findings:

1. Mildly handicapped students regressed less than regular students and had complete recoupment by November.

2. Behaviorally disordered students performed similarly to regular students with the exception of reading, which was lower. Recoupment was not complete by December.

3. Moderately and severely handicapped students tended to forget more rapidly, and recoupment was slower than for other groups of students. Speech and language recoupment rates were similar to those of other students and generally were completed by November.

4. Communication disordered groups showed little regression and had complete recoupment by October.

5. Hearing impaired and deaf students tended to perform almost identically to regular students with regard to forgetting and recoupment.

Based on their data analysis, Tilley, Cox and Stayrook concluded and recommended the following:

1. Regular education students seem to regress in late summer on academic tasks, as measured by short forms of the California Achievement Test (CAT). It is recommended that the administration give serious thought to providing regular summer school programs in late summer rather than the current practice of scheduling them right after school is out in spring.

2. Patterns of loss and recovery for students with handicaps are similar enough to those of regular students that the timing of summer program offerings could be the same for both groups as long as the service delivery structure contains provisions to accommodate exceptional needs of students with handicaps where necessary.

3. Given the unreliability of measuring handicapped students' performance, the .05 confidence interval is recommended for use in developing guidelines to determine which students require extended school year services.

4. Students with mild handicaps regress and recover at about the same rate as regular students, but their overall test scores are much lower than those of regular students.

5. Seriously behaviorally disabled, hearing impaired, and deaf students' patterns, rates, and performance levels on the California Achievement Test (CAT) were similar to those of students in the regular program.

6. Communication disordered students' patterns on a test of articulation were flat, and few students qualified for service. If they have more severe language acquisition problems, cutoff scores for language tests developed for moderately and severely handicapped students should be used.

7. Moderately and severely handicapped students' overall pattern of regression and recoupment looks like regular students; however, their rate of regression is much faster on all types of tests (e.g., cognitive, selfhelp, speech/language, occupational/physical therapy). Their recoupment is slower on cognitive test items, but on language, self-help, gross motor, and fine motor test items, their rate of recoupment is similar to that of students in the regular program.

8. Students who are deaf/blind or visually impaired were excluded from the study because the population sizes were too small for a separate statistical analysis. We recommend that the guidelines developed for the multihandicapped and mentally retarded-severe/profound be used.

\section{YEAR-ROUND SCHOOLING}

The rationale for including year-round schooling is logical. If mathematical language and processes require consistent maintenance over time and forgetting and recoupment studies show the significant summer losses in mathematics 
skill, as well as a significant amount of time needed to recoup the lost skill, year-round schooling seems a most logical solution.

Although most school districts resort to year-round schooling for economic or space reasons, an even more important and substantive argument should be made based on achievement, specifically for mathematics. Newman (1990) reported 630 year-round schools enrolling some 524,000 students. All Los Angeles public schools had adopted a year-round schedule by July 1990. Initially, approximately 100 of the 600 -plus schools were operating on a year-round schedule, accounting for about $20 \%$ of the students enrolled. The calendar is 90 days in school and 30 days off. Although the plan was adopted to relieve crowding, the most significant benefit may well be greater achievement. It is hoped that a sound research design will gather and analyze data from the Los Angeles district to shed light on the achievement question.

Newman cited a research study by Philadelphia-based public/private ventures that specifically documents "summer slippage" academically among children in at-risk populations. The cause cited is lack of home and community reinforcement over the long summer break. Newman also cited a research study by Adrian Van Mondfrans, Brigham Young University, showing that students on a year-round calendar make greater gains on test scores than those on traditional calendars. Utah, which has the fastest-growing school-age population in the nation, has the highest percentage of year-round schools in the nation. California has the greatest number of year-round schools.

Resistance to year-round schooling among teachers and patrons has been substantial. Newman cited school board president Jackie Goldberg: "One of the reasons we had so much resistance ... is because we didn't talk enough about the instructional purposes."

Newman also cited results in Orange County, Florida, concerning teacher resistance. "Initially, the teachers were negative," said George Segna, Executive Director of the Orange County Classroom Teachers Association, "but the more they learned about it, the more positive they became. They found that year-round schooling doesn't add days to the calendar, and they enjoyed the pace."

Current reform movements have advocated a longer school year since inception. Newman cited U.S. Senator Jeff Bingham (D-NM), who introduced a bill to examine the idea of lengthening the school year: "All studies indicate that our students get less instruction than students in other countries. Students in West Germany, Japan, Great Britain, and South Korea attend schools as much as 243 days per year." The average U.S. school year ranges from 170 to 182 days. Most advocates of extended school years tend to see 200 as a minimum number of days.
The June-to-September school vacation is one of the few things about schooling that remains unchanged. Originally based on the needs of an agrarian society, there seems to be no economic reason for the June-to-September vacation to remain that way based on the needs of society today.

Christie (1989) noted reasons other than overcrowding for considering year-round schooling:

1. Buildings and equipment already exist.

2. Teachers might be given extended contracts.

3. Administrative staffs already operate year-round.

4. Many fixed costs are independent of the number of months the school operates.

5. Many young people have difficulty making worthwhile use of the long summer vacation.

6. Increasing numbers of students are becoming involved in summer school programs for remediation, enrichment, and acceleration.

Research on achievement as it relates to year-round schooling is limited and generally is conducted over such a short time period that determining the true effect of year-round schooling on achievement is difficult.

After surveying 32 Iowa elementary schools, Beggs (1969) concluded that students lost the equivalent of 5 months of education in basic language and mathematics skills during the 3-month summer vacation. Harlan's (1973) research indicated that the year-round plan was more beneficial to students with intelligence scores below 100.

Merino (1983) raised the issue of needed longitudinal research. In an evaluation of the elementary program in Hayward, California, the results of the year-round program did not become apparent until after 4 years of implementation, when students on year-round schedules showed greater gains than students enrolled in the traditional school schedule.

\section{CONCLUSIONS AND RECOMMENDATIONS}

From the preceding discussion, the learning of language and mathematics indeed seems to be closely related. Learning mathematics and specialized language also seem to be highly influenced by continual reinforcement without prolonged interruptions such as summer vacation. This is true for regular students and students in special education alike. Research on year-round schooling, which eliminates lengthy interruptions, shows favorable results toward greater achievement.

These three conclusions speak strongly for the argument that much could be accomplished toward better learning 
and greater achievement, specifically in the areas of mathematics and language, by adopting year-round schooling. In spite of the resistance that might develop, those who do so have little or no solid research evidence that would defend retaining the June-September vacation pattern. Tradition and convenience constitute the argument the resistance advances.

What is needed above all else is well designed longitudinal research that will add to the existing research findings. Certainly, what is known at this point is that prolonged interruptions influence achievement negatively, whereas extended schooling and year-round schooling show a positive influence for greater achievement.

We suggest that year-round schooling offers a partial solution to raising achievement scores in mathematics. Further, we suggested that continual curriculum changes without some concomitant changes in other aspects of our schools cannot change the achievement picture. Certainly, national assessment studies do not support the notion that curriculum change alone can solve our problem of ranking near the bottom in the international studies comparing mathematics achievement.

In conclusion, various organizational patterns for the school calendar must be devised to eliminate prolonged interruptions in instruction, thus minimizing forgetting and minimizing the amount of instructional time needed for recoupment. As well, the frequent interruptions that occur daily must be diminished. No curricular change or change in methodology can hope to succeed when frequent and lengthy interruptions are tolerated as normal or acceptable. Acceptance of these interruptions in itself sends a signal to students concerning our view of the importance of instruction. It is time to return to the basics: uninterrupted instructional time.

\section{REFERENCES}

Arbordo, E. J. (1977). Evaluation report, Summer program of reading and mathematics for handicapped pupils in special education classes, Summer 1975. Washington, DC: Bureau of Elementary and Secondary Education, U.S. Office of Education, Department of Health, Education and Welfare.

Armstrong v. Kline, Civ. A. Nos. 78-172, 78-132, 78-133, E.D. Pennsylvania (1979).

Austin, G. R., Roger, D. G., \& Walbesser, H. H., Jr. (1972). The effectiveness of summer compensatory education: A review of the research. Review of Educational Research, 42(2), 171-181.

Baken, J. W. (1976). Inservice teacher training in a summer program for severely handicapped children: A summer can make the difference. Rehabilitation Literature, 37(3), 74-77.

Bateman, B. (1968). A pilot study of mentally retarded children attending summer day camp. Mental Retardation, 6(1), 39-44.

Beggs, D. L. (1969). The summer vacation-An internuption in learning. Illinois Journal of Education, January.
Beggs, D. L., \& Hieronymus, O. N. (1968). Uniformity of growth in the basic skills throughout the school year and during the summer. Journal of Educational Measurement, 5(2), 91-97.

Behrens, T. R. (1967). Final report, Demonstration project for the initiation of summer curriculum with special emphasis upon language acceleration for hearing impaired children. Washington, DC: Bureau of Education for the Handicapped, U.S. Office of Education, Department of Health, Education and Welfare.

Board of Education of the Hendrick Hudson Central School District v. Roley, 102 S. Ct. 3034, 73 L.Ed 2nd 690 (1982).

Breuckner, L. J., \& Distad, H. W. (1924). The effect of summer vacation on the reading ability of first grade children. Elementary School Journal, 24, 698-707.

Bruene, E. (1928). Effect of summer vacation on the achievement of pupils in the 4th, 5th and 6th grades. Educational Research, 18, 309-314.

Brown, L. F., \& Andrews, J. B. (1968). Status report: A summer school outdoor educational program for culturally disadvantaged educable mentally retarded children. Washington, DC: U.S. Office of Education, Department of Health, Education and Welfare.

Carpenter, Thomas, et al. (1984). Achievement in mathematics: Results from the national assessment. Elementary School Journal, 84(5), 485-496.

Chorost, S. B. (1975). Evaluation report: Summer program for reading and mathematics for handicapped pupils in special education classes (DSEPPS) severely emotionally handicapped, hearing impaired, multiply handicapped, preplacement, Summer 1975. Washington, DC: Bureau of Elementary and Secondary Education, U.S. Office of Education, Department of Health, Education and Welfare.

Christie, T. (1989). Investigation of the feasibility of year-round elementary education for the Lawrence Public Schools, Lawrence, Kansas. Ph.D. dissertation, University of Kansas, Lawrence.

Cone, T. E. (1984). Extended year program task force report, Des Moines, IA: Department of Public Instruction.

Cook, R. C. (1942). Vacation retention of fundamentals by primary grade pupils. Elementary School Journal, 43, 214-216.

Crawford v. Pittman, 708 F. 2d 10238 (5th Cir. 1983).

Edgar, E., Spence, W. M., \& Kenowitz, L. A. (1977). Extended school year for the handicapped. Is it working? Journal of Special Education, $11(4), 441-447$.

Elder, H. E. (1927). The effect of summer vacation on silent reading ability in the intermediate grades. Elementary School Journal, 27, 541-546.

Ellis, R. S. (1975). Evaluation report: Summer education program for neurologically and physically handicapped children, Summer 1975. Washington, DC: Bureau of Education for the Handicapped, U.S. Office of Education, Department of Health, Education and Welfare.

Fox, D. J., Wright, F., \& Goldstein, L. (1967). Summer 1967 clinics for speech handicapped children: Evaluation of New York Title I education projects 1966-67. Brooklyn: New York City Board of Education.

Fredericks, H. D., Anderson, R., Baldwin, V. L., Grove, D., Moore, W., \& Beaird, J. (1978). The identification of competencies of teachers of the severely handicapped (Project report). Monmouth, OR: Teaching Resources Division, Oregon State Agency for Higher Education.

Georgia Association of Retarded Citizens v. McDaniel, 1983-84 EHLR DEC. 555:251 (11th Cir. 1983).

Harlan, M. (1973). Academic achievement of students enrolled in a 45-15 continuous school plan. Doctoral dissertation, Northern Illinois University, DeKalb.

Hirsch, E. (1987). Cultural literacy. Boston: Houghton Mifflin.

Hourcase, J., (1977, April). Effect of a summer camp program on self-concept of mentally retarded young adults. Paper presented at Annual International Convention, Council for Exceptional Children, Atlanta. (ERIC Document Reproduction Service No. ED 139144). 
Irmina, M., Sister (1928). The effect of summer vacation on the retention of the elementary school subject. Catholic University American Educational Research Bulletin, 3, 99.

Joiner, L. M., Lodato, F. I., \& Stillman, M. (1972), Mentally retarded trainable children and educable pupils (Final report). New York: Teaching \& Learning Research Corp.

Keyes, N., \& Lawson, J. V. (1937). Summer vs. winter gains in school achievement, School \& Society, 46, 541-544.

Kohlberg, O. W. (1934). A study of summer time forgetting. Elementary School Journal, 35, 281-287.

Magliocca, L. O., \& Barker, H. (1981, August). Research review and recommendation regarding extended school year programming for handicapped pupils. Drake University, Des Moines, IA, Midwest Regional Resource Center.

McMahon, J. (1983). Extended school year programs. Exceptional Children, Feb., 457-360.

Merino, B. J. (1983). The impact of year-round schooling: A review of urban education, 18, 298-316.

Meyers, M., \& Burton, G. (1989, March). Yes, you can ... plan appropriate instruction for learning disabled students. Arithmetic Teacher, 36(7).

Minton, J. (1976). Summer 1976 program for deaf children: Evaluation report, evaluation period, July 2-August 13, 1976. Washington, DC: Bureau of Elementary and Secondary Education, U.S. Office of Education, Department of Health, Education and Welfare.

Morrison, J. C. (1924). Effect of summer vacations on learning. Ohio State University Educational Research Bulletin, 3 245-249.

National Council for Teachers of Mathematics (1989). Curriculum and evaluation standards for school mathematics. Reston, VA: Author.

National Council for Teachers of Mathematics (1991, March). Professional standards for teaching mathematics. Reston, VA: Author.

National Research Council (1989). Everybody counts. Washington, DC: National Academy Press.

Newman, M. (1990, April). Summertime blues, Teacher Magazine, 1(7), 16-19.
Parsley, K. M., \& Powell, M. (1962). Achievement gains or losses during the academic year and over the summer vacation period: A study of trend in achievement by sex and grade level among students of average intelligence. Genetic Psychology Monographs, pp. 285-342.

Polansky, D. W. (1979). A model summer employment program for deaf youth. American Annals of the Deaf, 24(4), 450-457.

Reigel, R. H., \& Taylor, A. M. (1973). Strategies in the classroom: A summer remedial program for young handicapped children. Washington, DC: Bureau of Education for the Handicapped, U.S. Office of Education, Department of Health, Education and Welfare.

Ross, D. A. (1982). A two-year comparative study of multiple-handicapped students who did and did not attend six-week summer school programs. Portland, OR: Multnomah County Education Service District.

Schrepel, M. \& Laslett, H. (1936). On the loss of knowledge by junior high school pupils over the summer vacation. Journal of Educational Psychology, 27, 299-303.

Soar, R. S., \& Soar, R. M. (1969). Pupil subject matter.growth during summer vacation. Educational Leadership, 26(6), 577-587.

Spivack, F. \& Koskey, E. (1972). Socially maladjusted and emotionally disturbed children: Summer 1972 Final Report, New York Teaching Research Corp. ED 085957.

Starkovich, P. (1972). Two year study of northwest regional center's summer sessions for preschool rubella, deaf-blind children. Final report. Northwest Regional Center Vancouver, WA, ED 072575.

Taylor, A. P., \& Pollock, B. (1968). A structured program of learning for moderately retarded deaf adults. Volta Review, 70, 114-117.

Tiedeman, H. R. (1948). Study in retention of classroom learning. Journal of Educational Research, 41, 516-531.

Tilley, W., Cox, L. S., \& Stayrook, N. (1986, Jan.). An extended school year validation study. (Management Information Paper, Report No. 86-2). Seattle: Seattle Public Schools.

Turner, K. (April, 1981). Theoretical and empirical considerations of the extended school year concept. Council for Exceptional Children Conference, New York, NY, 1981.

\begin{tabular}{|c|c|}
\hline INDEX & VOLUME 23 \\
\hline AUTHOR INDEX & CHRONOLOGICAL INDEX OF TITLES \\
\hline $\begin{array}{l}\text { Anderegg, M. L. (March 1991) } \\
\text { Capps, Lelon R. (May 1991) } \\
\text { Clark, Frances L. (February 1991) } \\
\text { Colarusso, Ron P. (April 1991) } \\
\text { Cox, Linda Simon (May 1991) } \\
\text { Deshler, Donald D. (February 1991) } \\
\text { Ehlers, Edwin S. (October 1990) } \\
\text { Ellis, Edwin S. (February 1991) } \\
\text { Kana, Thomas G. (April 1991) } \\
\text { Lenz, B. Keith (February 1991) } \\
\text { Mira, Mary P. (January 1991) } \\
\text { Myles, Brenda Smith (December 1990) and (March 1991) } \\
\text { Ruffin, Micca (October 1990) } \\
\text { Schumaker, Jean B. (February 1991) } \\
\text { Simpson, Richard L. (December 1990) } \\
\text { Thousand, Jacqueline S. (November 1990) } \\
\text { Tyler, Janet Siantz (January 1991) } \\
\text { Vergason, Glenn A. (March 1991) } \\
\text { Villa, Richard A. (November 1990) } \\
\text { Whelan, Richard J. (March 1991) } \\
\text { Zigmond, Naomi (September 1990) }\end{array}$ & $\begin{array}{l}\text { Rethinking Secondary School Programs for Students with Learn- } \\
\text { ing Disabilities (September 1990) } \\
\text { The Missouri Project-Parents As Teachers (October 1990) } \\
\text { Strategies for Educating Learners with Severe Disabilities Within } \\
\text { Their Local Home Schools and Communities (November } \\
\text { 1990) } \\
\text { The General Education Collaboration Models: A Model for Suc- } \\
\text { cessful Mainstreaming (December 1990) } \\
\text { Students with Traumatic Brain Injury: Making the Transition } \\
\text { from Hospital to School (January 1991) } \\
\text { An Instructional Model for Teaching Learning Strategies (Febru- } \\
\text { ary 1991) } \\
\text { Beyond the Regular Education Initiative and the Resource Room } \\
\text { Controversy (March 1991) } \\
\text { The Regular Education Initiative Without Waivers (March 1991) } \\
\text { Public Law 99-457, Part H. Infant and Toddler Programs: Status } \\
\text { and Implications (April 1991) } \\
\text { Improving the Learning of Mathematics in our Schools (May } \\
\text { 1991) }\end{array}$ \\
\hline
\end{tabular}

